\title{
Voskopitoechia chlupaci sp. nov. a Cantabrian (N Spain) Pragian uncinulid brachiopod with Bohemian affinities
}

\author{
JENARO L. GARCÍA-ALCALDE
}

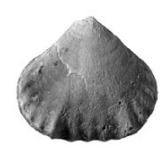

\begin{abstract}
A new species of Voskopitoechia, V. chlupaci sp. nov. from the Pragian of the Cantabrian Mountains (N Spain) is described. The genus Voskopitoechia was already known by its type-species, V. orbona, from the Pragian of Bohemia. The occurrence of both Voskopitoechia species in northern Gondwana is related to a large faunal turnover in the aftermath of the Sulcatus Event, and also coincided with the onset of tropical conditions that allowed the occurrence of the first Devonian reef-building episodes in Gondwana. The palaeobiogeographical distribution of Voskopitoechia likewise supports the increasing closeness in Pragian times of peri-Gondwanan terranes as Northern Iberia and Perunica. • Key words: palaeobiogeography, Sulcatus Event, Pragian, Perunica, Cantabrian Mountains.
\end{abstract}

GARCíA-AlCALDE, J.L. 2009. Voskopitoechia chlupaci sp. nov. a Cantabrian (N Spain) Pragian uncinulid brachiopod with Bohemian affinities. Bulletin of Geosciences 84(1), 149-154 (6 figures). Czech Geological Survey, Prague. ISSN 1214-1119. Manuscript received September 25, 2008; accepted in revised form January 6, 2009; published online February 25, 2009; issued March 31, 2009.

Jenaro L. García-Alcalde, Department of Geology (Paleontology), University of Oviedo, c/ Jesús Arias de Velasco, s/n, 33005 Oviedo, Asturias, Spain; jalcalde@geol.uniovi.es

The Lochkovian/Pragian transition in the Cantabrian Mountains (Northern Iberian Peninsula, Spain) (Fig. 1) shows singular stratigraphic features related both to the contemporary palaeogeography and to marked eustatic oscillations that occurred during a widespread and relatively important bio-event, the so-called Sulcatus (or Lochkovian/Pragian) Event (Barnes et al. 1996, Chlupáč \& Kukal 1988, García-Alcalde 1998, García-Alcalde et al. 2001).

During the Lochkovian/Pragian boundary time, the Cantabrian region drifted quickly northwards to tropical latitudes as a part of the vast North Gondwanan platform of the Rheic sea (Fig. 2). Shallow to very shallow shelf conditions were then typical features, although, some elongate, relatively deeper, intra-shelf basins also occurred (Ziegler 1988). At the northern platform margin, the Perunica micro-plate (Havlíček 1999), which faced the Baltica palaeocontinent, was separated from the margin by the northeastern end of the Rheic sea (Fig. 2).

Coupled with the general North Gondwana drift northwards towards the Euro-American palaeocontinent, the sea level worldwide was considerably lowered during most of Lochkovian. This regressive pulse brought in one of the most important Devonian low-stands and could be the main triggering agent of the anoxic Sulcatus Event. However, at the start of Pragian, the eustatic trend reversed drastically (corresponding to the beginning of Johnson et al.'s 1985 T-R cycle Ia). The geochemical, geophysical, sedimento- logical, and palaeobiological consequences of this twophase process were marked and constitute the framework of both the Sulcatus Event and the subsequent recovery period. (For a detailed description focused on the Cantabrian Mts, see García-Alcalde 1998 and García-Alcalde et al. 2001.)

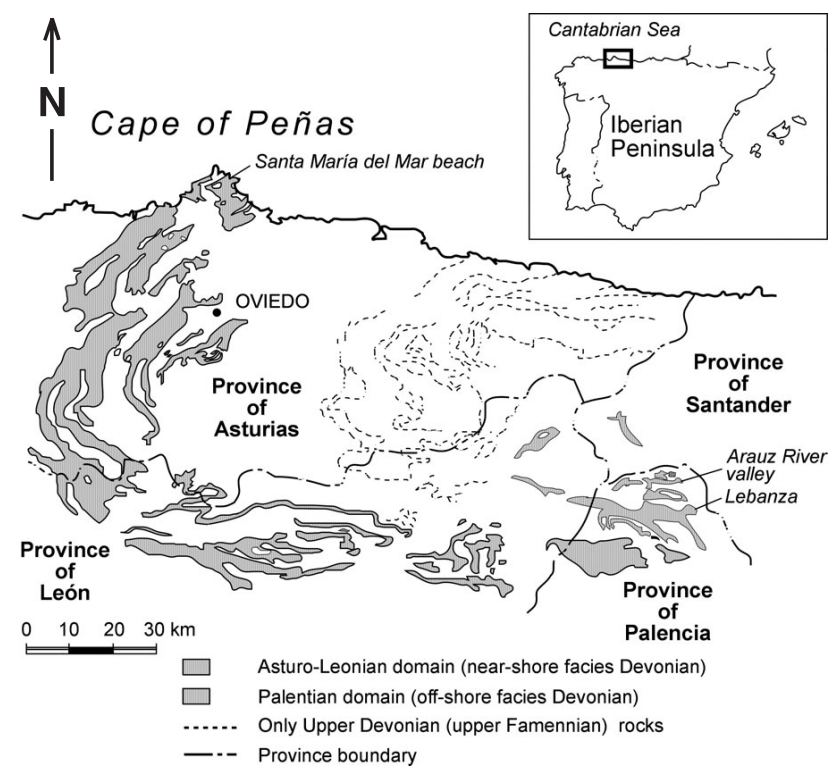

Figure 1. Devonian outcrops in the Cantabrian Mountain (northern Spain) and location of the Santa María del Mar beach, in the Asturo-Leonian domain, and of the Arauz river valley and Lebanza in the Palentian domain. 


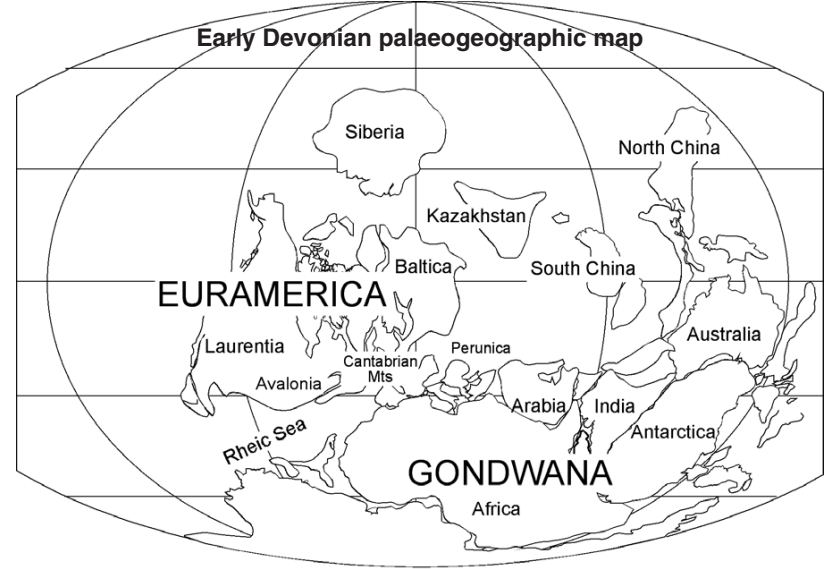

Figure 2. Paleogeographic location of the Cantabrian Mountains and Perunica terrains (based on Scotese 1997).

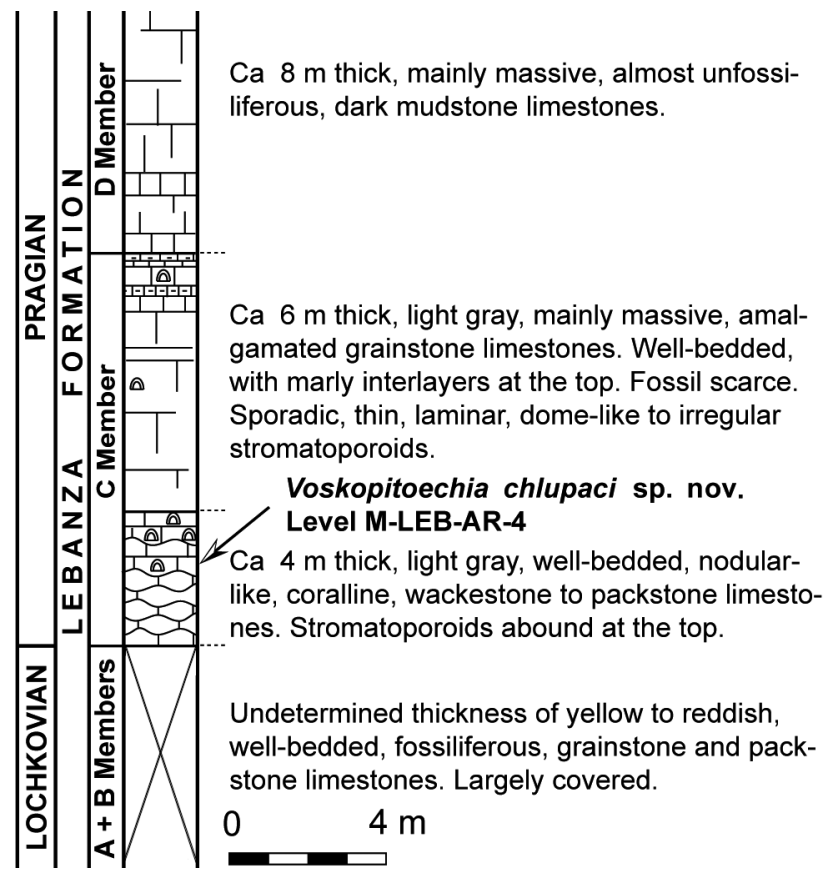

Figure 3. Stratigraphical position of V. chlupaci sp. nov. stratotype.

Regarding the subsequent effects of the consequences referred to above the occurrence of the first Devonian reef build-ups in Gondwana can be singled out. In some areas, such as Perunica, this reef development was very important and gave way to the well-known Koněprusy Facies, one of the most spectacular coralline Palaeozoic complexes. In the Cantabrian Mountains, reef development was much more modest. It originated as small patch reefs of tabulates, stromatoporoids, and colonial Disphyllidae (Zelolasma?), laterally grading into thin-bedded biostromal layers (Soto et al. in García-Alcalde et al. 2002).

The palaeogeographical low-latitude setting that favoured the occurrence of reef build-ups, likewise promoted an environmental homogenization and the occurrence of widespread distribution of shelly taxa (i.e. brachiopods; García-Alcalde 1999, 2003) on the Gondwanan platform. In this paper a new Ibarmaghian realm (Plusquellec 1987) Pragian brachiopod species, assigned to the Bohemian genus Voskopitoechia (V. chlupaci sp. nov.) is described. Voskopitoechia was known until now only by its type species $V$. orbona Havlíček, 1992, from the Koněprusy Limestone at Koněprusy, Voskop Quarry, Czech Republic, and more questionably by another unnamed, Pragian species from the Altai-Sayan region (Havlíček \& Vaněk 1998, p. 30). This fact further supports the increasing closeness between the Cantabrian Mountains and other peri-Gondwanan terranes, such as Perunica itself.

The stratotype of $V$. chlupaci sp. nov. occurs in the Palentian domain of the Cantabrian Mountains, in the Lebanza Formation in the lower part of the C Member (Krans et al. 1982), below massive lime mudstones (D Member) (Fig. 3). The C + D Members of the Lebanza Formation constitute the body of the so-called "massive member", remarkably raised on the terrain usually as rocky crests due to their greater relative resistance to erosion (Fig. 4). V. chlupaci sp. nov. likewise occurs in corresponding levels of the Nieva Fm. in the Asturo-Leonian domain (Fig. 1). As outlined above, this part of the Devonian succession records the development of the first Devonian reef episode in the Cantabrian Mts, coupled with a sea-level rise in the aftermath of the regressive Sulcatus Event. A remarkable faunal turnover characterized postevent times, with widespread evolution of many new brachiopod taxa, e.g., in the Cantabrian Mts, in addition to Voskopitoechia itself, "Anathyris", Plicathyris, Fascistropheodonta, Boucotstrophia, and Plicostropheodonta occur for the first time (García-Alcalde 1998).

\section{Systematic Palaeontology}

Superfamily Uncinuloidea Rzhonsnitskaya, 1956

Family Hebetoechiidae Havlíček, 1960

Subfamily Hebetoechiinae Havlíček, 1960

\section{Voskopitoechia Havlíček, 1959}

Type species. - V. orbona Havlíček, 1992. Pragian-lower Emsian. Czech Republic, Vinařice, Koněprusy and Zlíchov limestones.

\section{Voskopitoechia chlupaci sp. nov.}

Figures 5, 6

v. pars 1996 Markitoechia sp; García-Alcalde, fig. 2 (only Pragian forms, coet. excl.).

v. 1999 Markitoechia; García-Alcalde, p. 248. 

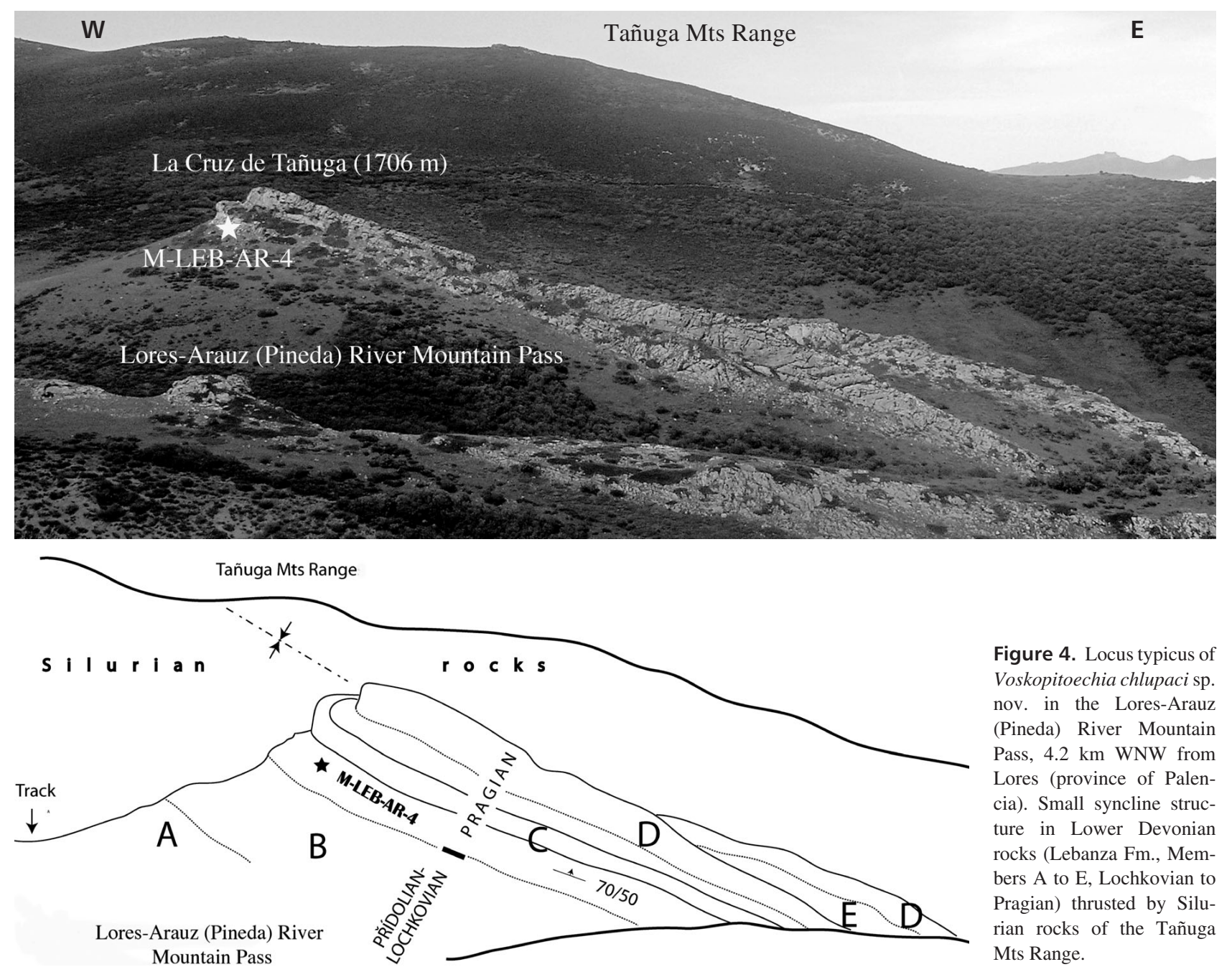

Derivatio nominis. - Species named in honour of the late Professor Ivo Chlupáč for his vast and important contributions to Devonian stratigraphic knowledge.

Locus and stratum typicum. - Cruz de Tañuga, a small mountain peak $200 \mathrm{~m}$ northeast from a mountain pass (situated at $1642 \mathrm{~m}$ above sea level) crossed by the track connecting the village of Lores with the Arauz River valley (known by local people as Arruz, and Pineda) on the southern foothills of the Sierra de Tañuga (Cervera de Pisuerga, Palencia Province), ca 4,2 km ENE Lores (Fig. 4). The locality is situated near the axis of a narrow syncline just north of the track. Lebanza Formation, C Member, level M-LEB-AR-4. Limestone with colonial rugose corals and stromatoporoids. The stratotype of V. chlupaci sp. nov. occurs in light gray wacke-packstone limestones with abundant stromatoporoids, 2-3 $\mathrm{m}$ above the base of Member C (Fig. 3) and the first occurrence of Vandercammenina sollei. The latter species is used in the Cantabrian Mountains as the regional guide-fossil for the base of the Pragian because the formal conodont index, Eognathodus sulcatus, is lacking there (García-Alcalde 1999, 2003; García-Alcalde et al. 1990, 2001).

Material. - Holotype DPO 38646 (Fig. 5A-D), 10 paratypes, DPO 38639-38645, 38647-38648 (paratype DPO 38647 figured in Fig. 5E-H), and another 4 specimens, DPO 38649, 38651-38653 quite fragmented and crushed, from the locus typicus and stratum typicum. DPO 30408 is from a different locality in the type-area, in the Arauz river valley, southern side of the Cortes syncline, same formation and member as the type material, in the interval between levels M-AR-48 and M-AR-51 (Pragian). 20 specimens, DPO 30059-30074 (DPO 30066 sectioned, Fig. 6), 30369-30371 and 30408 (DPO 30068 figured in Fig. 5M-P; DPO 30074 figured in Fig. 5I-L) from several localities near Lebanza village, south of the type-area, but from the same formation and member (Pragian). 2 specimens, DPO 39447-39478 from the El Escayo section, NW of Santa María del Mar beach (Castrillón, province of Asturias), Nieva Formation, level SMM-73/74 (GarcíaAlcalde et al. 1990). All the material is conserved in the 

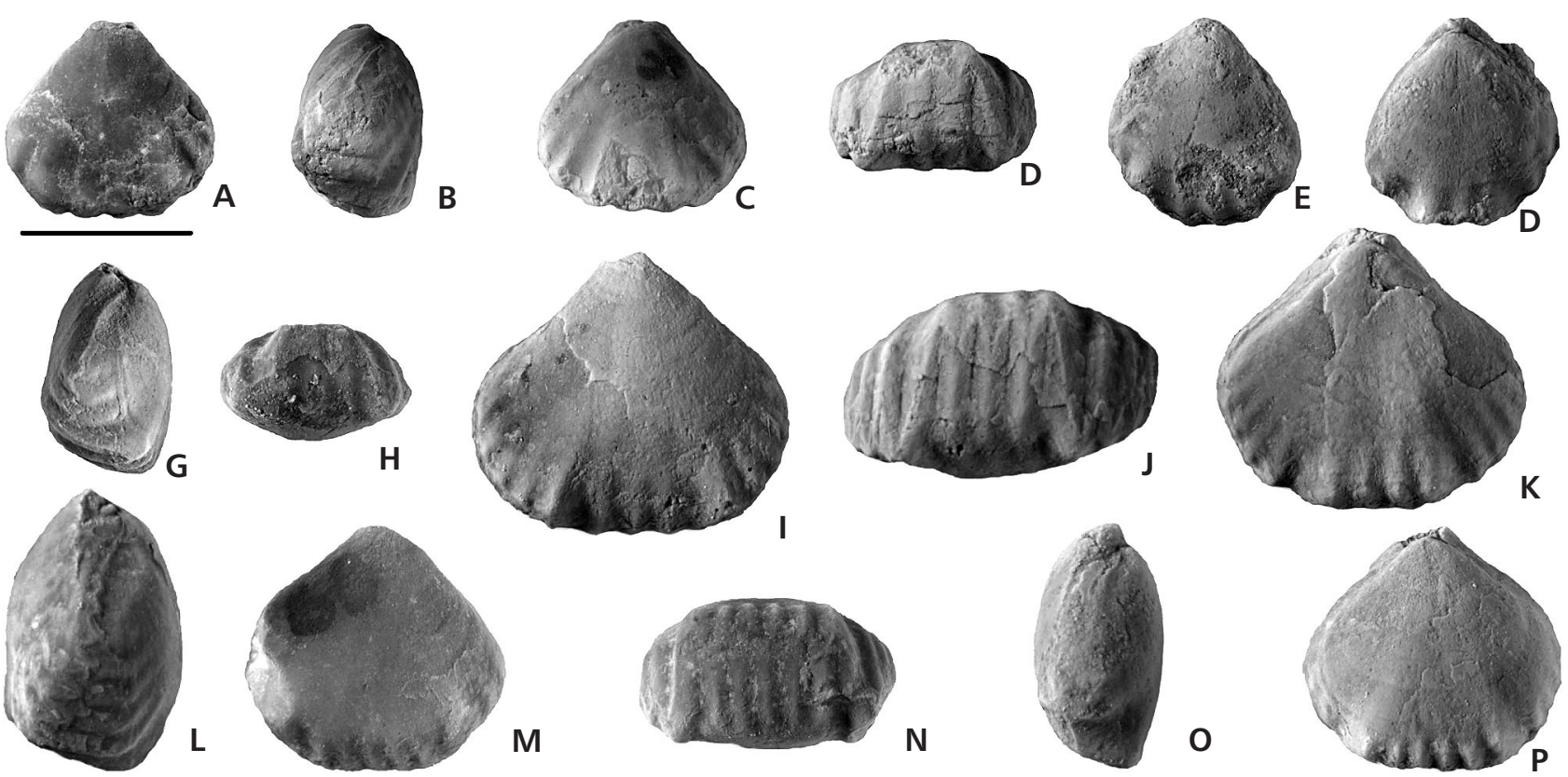

Figure 5. Voskopitoechia chlupaci sp. nov. • A-D - holotype DPO 38646, ventral, lateral, dorsal, and anterior views. • E-H - paratype DPO 38647, ventral, dorsal, lateral, and anterior views. • I-L - specimen DPO 30074, ventral, anterior, dorsal, and lateral views. • M-P - specimen DPO 30068, ventral, anterior, lateral, and dorsal views. Figures blackened with magnesium oxide; black bar represents 5 mm.

DPO repository, Geology Museum of the Oviedo University.

Diagnosis. - Small shell, sub-pentagonal, dorsi-biconvex, length and width equal, or slightly wider than long. Lateral and anterior valve margins curving abruptly towards the commissures. Paucicostate shell with low and rounded ribs, starting well anterior to the umbonal region, near the commissures, flattened and medially grooved to fit marginal spines on paries geniculatus. Fold and sulcus short, arising at mid-length; tongue well-developed; shallow, convex ventral sulcus, occupied by not more than 5 short ribs; faintly raised dorsal median fold with 1 to 6 ribs that reach the same level, or median ribs slightly overhanging the lateral ribs. Commissures strongly indented by ribs. Dental plates thin and short; dorsal median septum high and relatively thick; septalium very shallow filled by a large, bilobed cardinal process. Hinge plates undivided, slightly convex in the median part (connectivum?).

Description. - Shell growth bi-cyclic. Successive growth stages would be similar to other opposed, geniculated, paucicostate shells (i.e. Cerveratoechia cantabrica, GarcíaAlcalde 1998). The first brephic stage has not been directly observed, but according to the adult umbonal morphology would consist of 4.5-5 mm long, lenticular, longer than wide, flattened, biconvex shells with sharp commissures (concha plana stage; Westbroek 1967). Neanic stage starts at a growth stop that becomes evident in the thickening of the corresponding growth lamella and in the occurrence of the first radial ribs: one on the ventral sinus, two on the dorsal fold, 2-3 ribs on each side; commissures still remaining sharp. The ephebic stage is characterized by the shell being ca $6 \mathrm{~mm}$ or more in length, dorsi-biconvex, length and width equal, medially differentiated with narrow ventral sulcus and dorsal fold; sharp commissures, particularly the anterior one; increasing number of ribs, usually 2 on ventral sulcus, 3 on median fold, and up to a maximum of 4 on each side. The final, mature stage, starts in shells which are wider than long, $c a 6.3 \mathrm{~mm}$ or more in length, abruptly curved lateral and anteriorly, resulting in the development of a relatively low paries geniculatus (concha alta stage; Westbroek 1967); at this stage, 3-5 ribs occur in the ventral sulcus, 4-6 on the dorsal fold, and 5 or more on each side.

Adult shell dorsi-biconvex, small (5.6-7.5 mm length in $68 \%$ of specimens; max: $8.9 \mathrm{~mm}$ ), subpentagonal, longer than wide, ranging to wider than long $(\mathrm{a} / \mathrm{L}>1$ in $75 \%$ of specimens), low ( $\mathrm{g} / \mathrm{L}<0.74$ in $73 \%$ of specimens; g/L max: 0.83), ribbed, with both valves smooth umbonally. Fold and sulcus narrow (ventral sinus ca $45 \%$ of the shell width), well bounded, short, arising anterior to mid-length. Convex, shallow sulcus; round, low ribs with narrower inter-costal intervals, starting at 2/3 of length; one to five ribs on ventral sulcus, two to six on median fold ( $3 / 2$ to $4 / 3$ in $72 \%$ of specimens; $2 / 1$ and $6 / 5$ observed in a single specimen); $2-7$ ribs on each side ( $3 / 3$ plus $3 / 4$ plus $4 / 4$ in $61 \%$ of specimens). Rectangular, rather low, convex, antero-ventrally to dorsally directed tongue. Low, very short, flattened median dorsal fold with ribs at the same level or median ribs slightly overhanging the lateral ribs. 


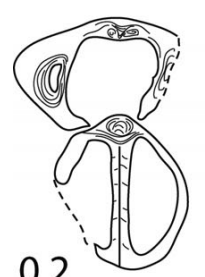

0.2

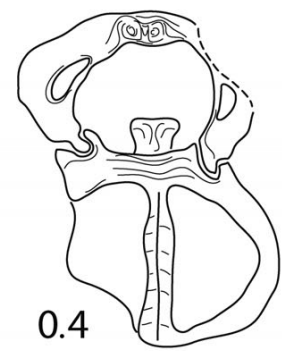

$5 \mathrm{~mm}$

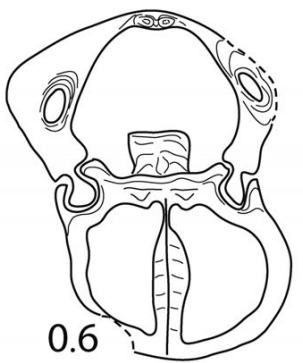

0.6

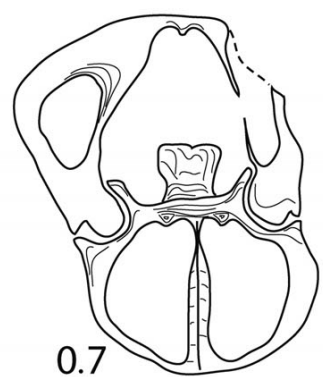

0.7
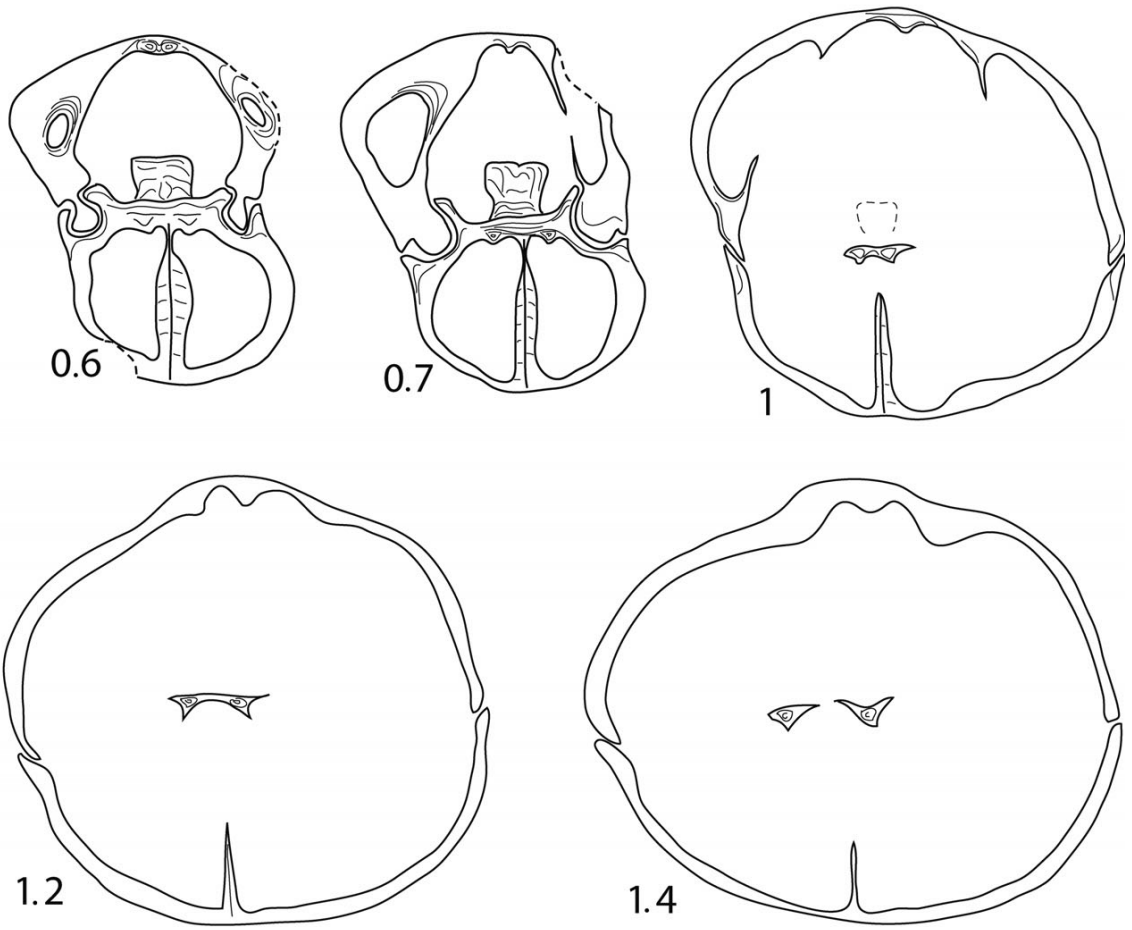

1.4

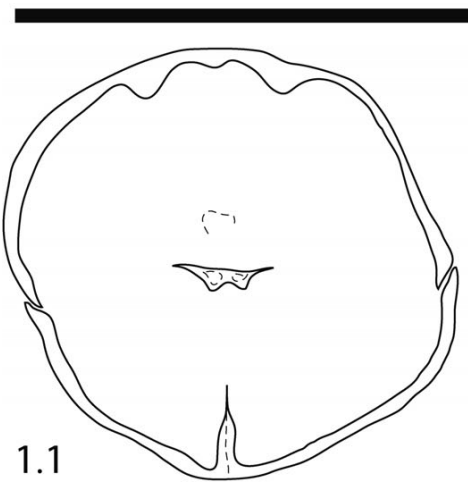

1.2

Figure 6. Voskopitoechia chlupaci n. sp. Camera lucida, transversal serial sections of specimen DPO 30066 . Distances measured in mm from the shell apex.

Ventral valve faintly and evenly convex, except at the anterior margin where it abruptly turns towards the commissure bending at a $\mathrm{ca} 90^{\circ}$ angle; maximum height of valve at mid-length or slightly anterior; ventral beak sub-erect, pierced by a minute, mesothyrid, circular foramen, bounded by a well developed deltidium; apical angle $c a$ $90^{\circ}\left(86^{\circ}\right.$ to $94^{\circ}$ in $50 \%$ of specimens). Dorsal valve strongly convex in the umbonal region, becoming evenly convex up to the anterior margin where it abruptly bends in a $c a 90^{\circ}$ angle towards the commissure. Umbonal sides of both valves well defined, bordering narrow, oval, flattened, lunular zones. Lateral sides of valves abruptly bending towards the commissures, where they form an angle close to but less than $180^{\circ}$. Paries geniculatus not high, particularly low in the dorsal valve where the anterior margin is nearly coincident with the commissure itself; on paries geniculatus ribs are flattened and medially grooved near the commissure; zig-zag striae barely visible due to shell abrasion; rather long, marginal spines prolonged in each valve along the paries geniculatus. Commissures strongly indented by ribs, anterior commissure trapezoidal, uniplicate.

Dental plates thin and short, close to valve walls. Well-impressed ventral muscle field, divided by a relatively high myophragm. Hinge plate undivided, convex medially (connectivum?). Septalium minute, filled by callus, resting on a short, high and relatively thick median septum. Cardinal process large, faintly bilobed, reaching the anterior end of hinge plate. Crural bases close to one another.
Discussion. - Voskopitoechia chlupaci sp. nov. was earlier assigned by the author to the genus Markitoechia Havlíček, 1959 , because of its general shape and lack of data on its internal structure. However, recently produced serial sections of $V$. chlupaci (Fig. 6) refute that assignment because this species lacks both a defined paries geniculatus in the anterior part of the dorsal valve as well as the very high, rodlike cardinal process of Markitoechia.

V. orbona Havlíček, 1992 differs in being smaller, with commissures gently undulate to nearly smooth. It also differs in the higher number of ribs (average of 17 in the former against 14 in $V$. chlupaci), and in having a much thinner middle dorsal septum and a clearly bilobed cardinal process.

A poorly known species of the Pragian of the Altai-Sayan region, Septalaria matercula (Barrande, 1847) (Alekseeva et al. 1970) has, without discussion, been included in Voskopitoechia by Havlíček \& Vaněk (1998, p. 30). Lack of morphological data including serial sections prevents us from comparing it with the well-known Voskopitoechia species.

\section{Conclusions}

The occurrence of the Bohemian brachiopod genus Voskopitoechia in the Pragian of the Cantabrian Mts (N Spain) is interpreted as proof of the increasing closeness among peri-Gondwanan terranes such as the Northern Iberian Peninsula and Perunica. On the other hand, the palaeobiogeographical distribution of the taxon is related to a large faunal 
turnover following the Sulcatus Event in a tropical palaeogeographical setting that allowed the onset of reef conditions in North Gondwana for the first time in the Devonian.

\section{Acknowledgments}

This paper is related to IGCP Project 499 "Evolución de los ecosistemas y climas durante el Devónico", and has been financed by the MEC-05-CGL 2005-03715 Project "Fases de desarrollo de asociaciones de corales y estromatoporoideos en el Devónico inferior de la Cordillera Cantábrica (NO de España) y relación de estos sucesos con eventos geo-biológicos" and FEDER funding. I greatly thank and acknowledge my good friend R.B. Blodgett for the careful correction of English. Likewise I acknowledge corrections and suggestions by referee U. Jansen, and new data on the Voskopitoechia distribution provided by the Editor, J. Frýda.

\section{References}

AlekseEVA, R.E., Gratsianova, R.T., Elkin, E.A. \& KULKOV, N.P. 1970. Stratigrafiya i brakhiopody Nichnego Devona Severo-Bostochnogo Salaira. Akademiya Nauk SSSR, Sibirskoe Otdelenia. Trudy Instituta Geologii I Geofizikhi, Bulletin 72, 1-188. [in Russian]

Barnes, C., Hallam, A., Kaljo, D., Kauffman, E.G. \& WALLISER, O.H. 1996. Global event stratigraphy, 319-333. In WALLISER, O.H. (ed.) Global events and event stratigraphy in the Phanerozoic. Springer-Verlag, Berlin.

CHLUPÁČ, I. \& KUKAL, Z. 1988. Possible global events and the stratigraphy of the Paleozoic of the Barrandian (CambrianMiddle Devonian, Czechoslovakia). Sborník geologických věd, Geologie 43, 83-146.

GARCIA-AlCALDE，J.L. 1996. El Devónico del dominio Astur-Leonés en la Zona Cantábrica ( $\mathrm{N}$ de España). Revista Española de Paleontología, $n^{o}$ extraordinario, Jornadas de Paleontología, Madrid 1994, 58-71.

GARCÍA-ALCALDE, J.L. 1998. Devonian events in northern Spain. Newsletters in Stratigraphy 36(2/3), 157-175.

GARCíA-AlCALDE, J.L. 1999. Nuevo género de braquiópodos rinconélidos del Praguiense (Devónico Inferior) de la región cántabro-celtibérica (España). Revista Española de Paleontología 14(2), 247-255.

GARCÍA-AlCALDE, J.L. 2003. Bimeristina binnekampi n. g., n. sp., meristeloideo (braquiópodo) del Devónico Inferior (Praguiense) de España. Revista Española de Paleontología 18(1), 103-112.

García-Alcalde, J.L. ARbizU, M., García-LóPeZ, S., Leyva, F., Montesinos, R., Soto, F. \& TRUyols-MasSONI, M. 1990. Devonian stage boundaries (Lochkovian/Pragian, Pragian/Emsian, and Eifelian/Givetian) in the Cantabric region (NW Spain). Neues Jahrbuch Geologie und Paläontologie Abhandlungen 180(2), 177-207.

García-Alcalde, J.L., ARbizU, M. \& TRUyols-Massoni, M. 2001. Extinciones masivas en el Devónico, 125-145. In
GÁMEZ, J.A. \& LiÑÁN, E. (eds) La Era Paleozoica. El desarrollo de la vida marina. Homenaje al Profesor Jaime Truyols, Memorias de las VII Jornadas Aragonesas de Paleontología. Institución "Fernando el Católico", Diputación de Zaragoza.

Garcia-AlCALDE, J.L. (coordinator), CARLS, P., PARdO Alonso, M.V., SANZ LóPez, J., SOTO, F., TRUyOlsMASSONI, M. \& VALENZUELA-RíOS, J.I. 2002. Devonian, 67-91. In GibBons, W \& MoREnO, T. (eds) The Geology of Spain. 649 pp. The Geological Society, London.

HAVLÍČEK, V. 1959. Rhynchonellacea im böhmischen älteren Paläozoikum (Brachiopoda). Věstník Ústředního ústavu geologického 34(1), 78-82.

HAVLÍČEK, V. 1960. Bericht über die Ergebnisse der Revision der Böhmischen Altpaläozoischen Rhynchonelloidea. Věstník Ústředního ústavu geologického 35(3), 241-244.

HAVLíčEK, V. 1992. New Lower Devonian (Lochkovian-Zlichovian) rhynchonellid brachiopods in the Prague Basin. Sborník geologických věd, Paleontologie 32, 55-122.

HAVLÍČEK, V. 1999. Perunica microplate: relation to Ukrainian Shield, mid-Bohemian rift, and hypothetic large-scale overthrusts in central Bohemia. Věstník Českého geologického ústavu 74(1), 75-81.

HAVlíčEK, V. \& VANĚK, J. 1998. Pragian brachiopods, trilobites, and principal biofacies in the Prague Basin (Lower Devonian, Bohemia). Sborník geologických věd, Paleontologie 34, 27-109.

Johnson, J.G., KLAPPER, G. \& SANDBERG, C.A. 1985. Devonian eustatic fluctuations in Euramerica. Bulletin of the Geological Society of America 96, 567-587.

DOI 10.1130/0016-7606(1985)96<567:DEFIE >2.0.CO;2

KRANS, T.F., GUIT, F.A. \& OFWEGEN, L.P. 1982. Facies patterns in the Lower Devonian carbonates of the Lebanza Formation (Cantabrian Mountains, province of Palencia, NW Spain). In KullmanN, J., SChÖNENBERG, R. \& WiedmanN, J. (eds) Subsidenz-Entwicklung im Kantabrischen Variszikum und an passiven Kontinentalrändern der Kreide. Teil 1. Variszikum. Neues Jahrbuch Geologie und Paläontologie Abhandlungen 163(2), 192-211.

PlusQuellec, Y. 1987. Révision de Michelinia transitoria Knod, 1908 (Tabulata, Dévonien de Bolivie). Annales Société Géologique du Nord 105 (pour 1985) 4, 249-252.

RZHONSNITSKAYA, M.A. 1956. Nadsemeistvo Rhynchonellacea Gray, 1848 (in Russian). In KIPARISOVA, L.D., MARKOVSKII, V.P. \& RADCHENKO, G.P. (eds) Materialy po Paleontologii, Novye Semeistva i Rody, Vsesoiuznyi Nauchno-Issledovatel'skii Geologicheskii Institut (VSEGEI), Materialy (Paleontologiia) 12, 53-56.

WEStBROEK, P. 1967. Morphological observations with systematic implications on some Palaeozoic Rhynchonellida from Europe, with special emphasis on the Uncinulidae. Leidse Geologische Mededelingen 41, 1-82.

ZIEGLER, P.A. 1988. Laurussia - the Old Red continent, 15-48. In MCMILlan, N.J., EMBRY, A.F. \& GLASS, D.J. (eds) Devonian of the World. Proceedings of the $2^{\circ}$ International Symposium on Devonian System 1. Calgary, Canada. 